\title{
Video-assisted intercostal nerve cryoablation in managing intractable chest wall pain
}

\author{
Ian Hunt, FRCS, Donna Eaton, FRCS, Omar Maiwand, FRCS, and Vladimir Anikin, FRCS, Harefield, \\ Middlesex, United Kingdom
}

\section{CLINICAL SUMMARY}

A 52-year-old women was referred to our unit with severe pain in the right side of the chest, having been kicked in the right flank by a horse 10 years earlier. At the time she sustained fractures to the right 10th, 11th, and 12th ribs and briefly required hospitalization. The pain was sharp and stabbing in nature. Standard oral analgesia including nonsteroidal antiinflammatory drugs was ineffective. She obtained little relief from opiates and was reluctant to take them long term. Some transient analgesia was obtained through epidurals and intercostal nerve blocks. She had been managed with gabapentin $800 \mathrm{mg}$ twice daily and amitriptyline $25 \mathrm{mg}$ daily long term.

She had no relevant medical history and clinical examination was unremarkable apart from an exquisitely hypersensitive area in the right flank. No obvious deformity was noted, but she had restricted chest wall movement owing to pain. Initial baseline investigations including chest radiograph showed no abnormalities. The rib fractures had healed without deformity. Magnetic resonance imaging revealed no soft tissue abnormality.

She was admitted the day before the operation and underwent an intercostal nerve block with lidocaine by the operating surgeon (V.A.) to assess exact location of intercostal nerves affected and effectiveness of blockade. The area was marked. The next day, after single lung ventilation and appropriate isolation under a general anesthetic, a single $10-\mathrm{mm}$ port was inserted anterolaterally into the 7th intercostal space and the lung was retracted medially. A straight $15-\mathrm{cm}$ long insulated cryoprobe with a tip diameter of $2 \mathrm{~mm}$ (designed and modified by one of us [O.M.] and manufactured by Spembly, Andover, United Kingdom) was inserted percutaneously close to the paraspinal junction at the previously marked sites and positioned under thoracoscopic guidance (Figure 1). The area close to the affected intercostal nerve in the 10th intercostal space was frozen until an ice ball could clearly be seen (Figure 2) for about 2 minutes. Parietal pleura remained intact. This was repeated in the 11th and 12th intercostal spaces. No signs of bleeding were noted. A single $24 \mathrm{~F}$ chest drain was placed and removed the following day. No postoperative complica-

From Harefield Hospital, Harefield \& Brompton NHS Trust, Harefield, Middlesex, United Kingdom.

Disclosures: None.

Received for publication Oct 12, 2008; revisions received Dec 13, 2008; accepted for publication Dec 28, 2008.

Address for reprints: Ian Hunt, FRCS, Harefield Hospital, Harefield, Middlesex, UB9 6JH United Kingdom (E-mail: ianjhunt@gmail.com).

J Thorac Cardiovasc Surg 2010;139:774-5

$0022-5223 / \$ 36.00$

Copyright (c) 2010 by The American Association for Thoracic Surgery doi: $10.1016 /$ j.jtcvs.2008.12.039

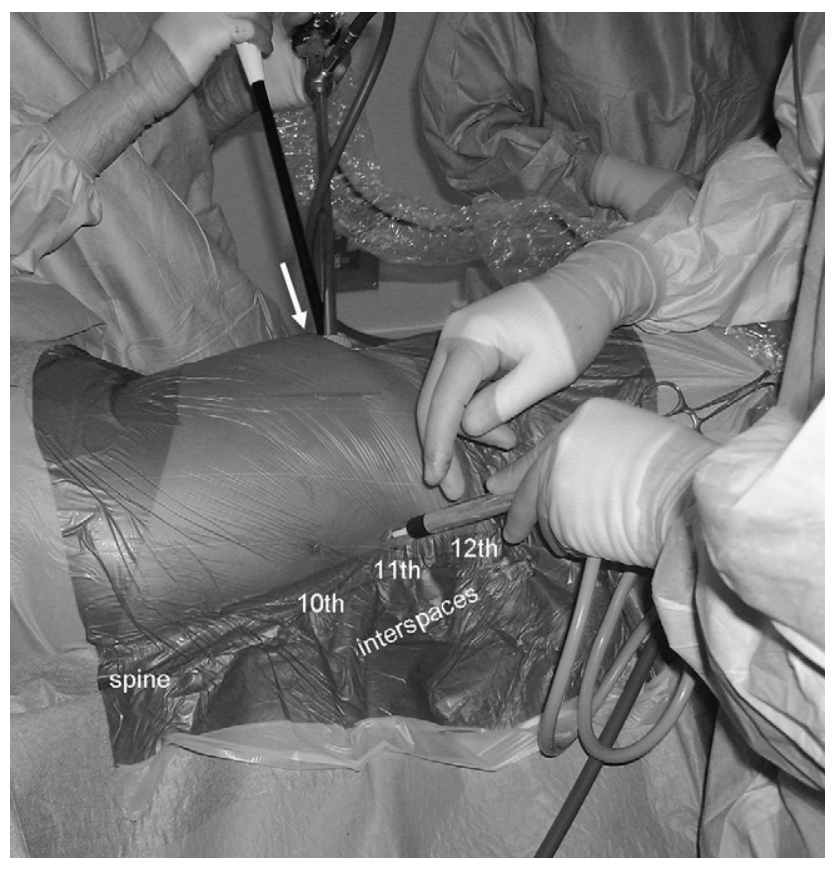

FIGURE 1. Patient is in the left lateral decubitus position. Percutaneous placement of cyroprobe lateral to the spine is performed under thorascopic guidance at the premarked 10th, 11th, and 12th intercostal spaces. An endoscopic lung retractor and thoracoscope was inserted through a single anterolateral $10-\mathrm{mm}$ port placed in the seventh intercostal space (white arrow).

tions were noted and the patient had immediate relief of her chest wall neuralgia. Her medications were continued for 4 weeks. At 9 months she has had no further neuralgia, is completely pain free, and takes no medication.

\section{DISCUSSION}

Cryoablation for intercostal neuralgia is a widely established albeit infrequently used modality for managing intractable chest wall pain and compares favorably with other techniques. ${ }^{1-3}$ The biological effect of "deep cold" to around $-60^{\circ} \mathrm{C}$ on the nerve in preserving nerve sheath and connective tissue and effectiveness has been studied and described. ${ }^{4}$ However, in patients in whom cryoablation is performed electively, typically at the time of thoracotomy, closure issues of subsequent neuralgias or chronic postthoracotomy pain syndromes have been raised. ${ }^{3}$ Recent reports of radiologically guided percutaneous cryoablation have renewed interest in managing this difficult group of patients with intractable chest wall neuralgia. ${ }^{5}$ We have described the first experience of combining cryoanalgesia with video-assisted thoracoscopy in a patient with intractable chronic chest wall neuralgia. 


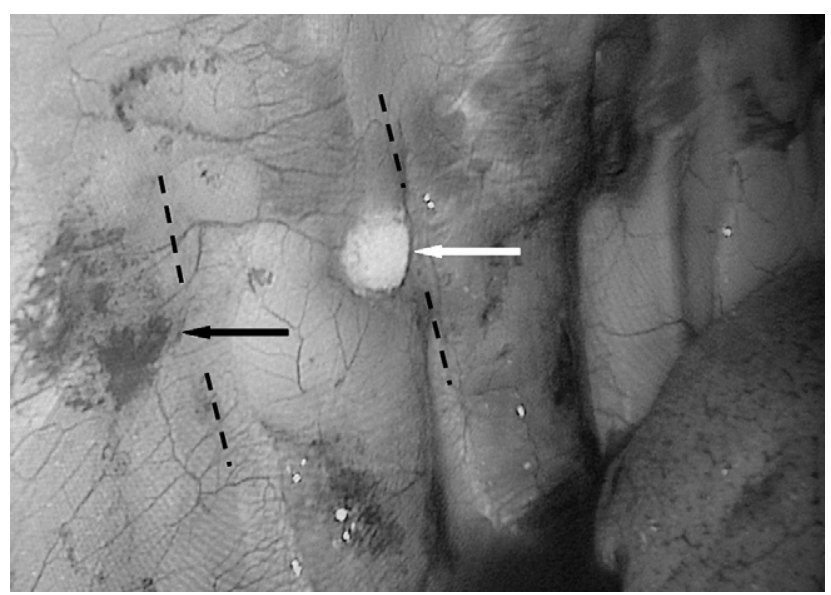

FIGURE 2. Thoracoscopic image demonstrating formation of ice ball in the affected intercostal space (white arrow) above the paravertebral sulcus (obscured by overlying lung). A previous site of cyroprobe application in the intercostal space below can be seen (black arrow). The black dashed lines represent the lower margins of the 11th and 12th ribs.

The thoracoscopic technique uses readily available instruments and allows for the safest approach, placement, and application of the cyroprobe under direct vision. It avoids repeat intercostal nerve blocks and epidurals and avoids the potential for pneumothorax that is inherent from "blind" percutaneous approaches. We have used separate punctures and direct placement of the cyroprobe into the intercostal spaces affected rather than placing the probe through the port so as to preserve pleura, "focus" the iceball's effect, and maintain accuracy of localization. It would not be unrea- sonable to adapt the technique and attempt a transpleural application of the probe through a single port, thereby avoiding separate stab incisions over the intercostal spaces affected, although for the reasons mentioned the cyroanlagesic effect may be reduced. The position of the anterolateral $10-\mathrm{mm}$ port in the seventh intercostal space allows simple retraction of the lung medially and excellent views of the paravertebral area. The need for decortication in postthoracotomy patients with intercostal neuralgia may add some difficulty to an otherwise simple procedure, but additional port placements and careful adhesiolysis does not preclude this approach.

In summary, this single-port minimally invasive technique allows multiple safe, precise, and direct applications of the cyroprobe to the areas affected and eliminates the need for further repetitive intercostal nerve blocks, epidurals, and the need for long-term medication.

\section{References}

1. Maiwand MO, Makey AR, Rees A. Cryoanalgesia after thoracotomy: improvement of technique and review of 600 cases. J Thorac Cardiovasc Surg. 1986;92:291-5.

2. Pastor J, Morales P, Cases E, Cordero P, Piqueras A, Galán G, et al. Evaluation of intercostal cryoanalgesia versus conventional analgesia in posthoracotomy pain. Respiration. 1996;63:241-5

3. Detterbeck FC. Efficacy of methods of intercostal nerve blockade for pain relief after thoracotomy. Ann Thorac Surg. 2005;80:1550-9.

4. Moorjani N, Zhao F, Tian Y, Liang C, Kaluba J, Maiwand MO. Effects of cryoanalgesia on post-thoracotomy pain and on the structure of intercostal nerves: a human prospective randomized trial and a histological study. Eur J Cardiothorac Surg. 2001;20:502-7.

5. Byas-Smith MG, Gulati A. Ultrasound-guided intercostal nerve cryoablation. Anesth Analg. 2006;103:1033-5.

\title{
The Sorin Freedom SOLO stentless aortic valve: Technique of implantation and operative results in 109 patients
}

\author{
Thierry Aymard, MD, Friedrich Eckstein, MD, Lars Englberger, MD, Mario Stalder, MD, \\ Alexander Kadner, MD, and Thierry Carrel, MD, Berne, Switzerland
}

Aortic valve replacement with a biological prosthesis is nowadays increasingly performed inasmuch as tissue valves

\footnotetext{
From the Department of Cardiovascular Surgery, Swiss Cardiovascular Center, University Hospital Berne, Switzerland.

Disclosures: None.

Received for publication Nov 28, 2008; revisions received Dec 26, 2008; accepted for publication Jan 19, 2009; available ahead of print Oct 9, 2009.

Address for reprints: Thierry Carrel, MD, Department of Cardiovascular Surgery, University Hospital Berne, CH-3010 Berne, Switzerland (E-mail: thierry.carrel@ insel.ch).

J Thorac Cardiovasc Surg 2010;139:775-7

$0022-5223 / \$ 36.00$

Copyright (c) 2010 by The American Association for Thoracic Surgery

doi:10.1016/j.jtcvs.2009.01.011
}

have improved regarding hemodynamic performance and durability, although they leave younger patients $(<60-65$ years) at risk for reintervention. ${ }^{1}$ The first generation of stentless valves usually required two suture lines at the annulus level and above. The second generation includes adaptation of the outside profile of the framework to simplify technique of implantation. Whether this change in design will crucially improve the long-term performance is currently unknown.

We summarize the technique of implantation and the early performance of a consecutive series of 109 patients who received a Sorin Freedom SOLO stenteless tissue valve (Sorin Biomedica Spa, Saluggio, Italy). 